Laboratory animals

\section{Research alarm at Israeli bill}

Rehovot

ISRAELI researchers are concerned that a bill for the regulation of experiments on animals now before the Knesset will, if passed, seriously impede research.

Introduced by M.K. Eliahu Speiser, it prohibits experiments "except where they are essential", Exactly what will be considered essential is to be defined by Minister of Health Mordechai Gur after consultation with a special nine-member advisory committee, which would include two doctors, two veterinarians, a representative of the Association for the Prevention of Cruelty to Animals, the director of the Biblical Zoo, representatives of Tel Aviv University and Bar-Ilan University and, last but not least, a rabbi recommended by the Minister of Religious Affairs.

The bill calls on each research centre to appoint a person who will supervise experiments on animals and who would bear criminal responsibility - which could mean a fine of up to US\$17,000 and/or a year in gaol - if the regulations governing such experiments are violated by anyone at his institution.

Weizmann Institute Professor Benjamin Geiger, who heads the institute's committee of experimental animal users, agrees that experiments must be regulated but is not pleased with the bill as it now stands. What bothers him in particular is the makeup of the proposed advisory committee, which he believes should be composed primarily of active scientists with both a concern for the welfare of animals and an understanding of research needs. Such people would be aware of the pitfalls involved in any attempt to define "essential research". After all, Geiger notes, "probably not more than 10 per cent of all experiments yield applicable results, but if you don't carry out the whole 100 per cent you'll never reach the important 10 per cent",

Geiger also challenges those who would bar experiments on animals if the results are "only" of industrial or commercial significance. "Whatever importance one attaches to cosmetics, for example, it would be irresponsible to market new ones before they have been tested on animals", he declares.

Finally, Geiger does not think that the problem of animal mistreatment is likely to be widespread in Israel because major research centres here already abide by their own strict animal welfare regulations as well as those set down by the US National Institutes of Health and other grantmaking agencies.

The head of the Weizmann Institute's "Helsinki committee" (for approving experiments involving human beings), Professor Irun Cohen, raises another question. "How is it possible", he asks, "to have an outside body threaten scientists who use animals in their experiments with the imposition of a stiff fine and even a gaol sentence while allowing them to police themselves when it comes to studies on people?"'

The Speiser bill is supported by Israel's Animal Liberation Group headed by Dr Andrew Menashe, a veterinarian with the Israel Society for the Prevention of Cruelty to Animals. In fact, Menashe thinks the bill does not go far enough, and he looks forward to the day when tissue culture tests and computer modelling will be substituted for all experiments on animals.

Like his counterparts elsewhere, Menashe also argues that tests on animals say very little about people. While noting that in vitro studies are adequate in some cases, in others, he argues, "you can't jump straight from Petri dishes to people".

Speiser agrees. Indeed, as an ex-biologist whose wife is a doctor, he realizes the importance of biological research, including that carried out on animals. "But", he declares, "these experiments must be properly supervised, and they aren't at present."

Nechemia Meyers

\section{Academic open shop}

Tokyo

JAPAN'S Ministry of Education is shortly to take steps to loosen up the academic system by enabling people from the non-academic world to become university professors.

At present, a strict set of ordinances, the university chartering criteria, makes it virtually impossible for anyone who has not followed a conventional academic career to become a professor or assistant professor in a state university. A professor must, for example, have either a doctorate or equivalent university research experience, or must have taught for more than a certain number of years at a university. Under the regulations now being planned, any person "recognized as competent in education and research" would be considered as eligible for a professorial post.

The change comes in response to the rapid growth in the number of highly talented researchers working outside the academic system - in research laboratories in private industry for example. Similarly, other trained people who could have something to offer the universities judges, lawyers, ex-ambassadors and journalists, for example - will become eligible for university posts. Indeed, many such people already lecture in universities but are restricted to the status of "part-time instructor". If this injection of "new blood" proves successful, it is likely that further changes will be made to allow foreigners the same access to university posts.

Alun Anderson
New Year firs Soviet yolki substitutes

CONSCIENTIOUS Soviet citizens should celebrate the coming new year without the traditional decorated fir-tree (yolka), the weekly Literaturnaya Gazeta urged at the beginning of October. A special correspondent from Armenia, Zorii Balayan, gave a glowing account of the 25-year campaign to outlaw the felling of fir-trees for yolki which resulted, last New Year, in not a single fir-tree being sacrificed to the festivities. The outcome, Balayan wrote, was an estimated saving to the economy of some 1.5 million trees which could now go to the paper and cellulose mills, the building industry or for the manufacture of vitamin C. Who will follow the Armenian example, asked the Literaturnaya Gazeta?

This is not the first time that yolki have been discouraged in what is now the Soviet Union. In 1914, Christmas trees were banned by the Holy Synod of the Orthodox Church as a "pro-German" influence (in spite of more than 200 years of cultural acclimatization since their formal introduction as part of Peter the Great's policy of "westernization"). They made a full come-back into Soviet life in 1941-42, when the necessities of war demanded the fostering of all national traditions, properly cleared of undesirable class and/or religious connotations.

Armenia, which is far distant from the North European traditions which engendered the mid-winter custom of decorating fir-trees, must have seemed a suitable area from which to eradicate the custom altogether. The first law forbidding the felling of yolki was passed in 1959, but in spite of numerous "educational" campaigns, felling of firs stopped only when every family could be provided with a reasonable plastic substitute.

Meanwhile, elsewhere in the Soviet Union, particularly in the northern and western republics, the annual felling of trees, including "poaching" from parks and nature reserves, still persists. A somewhat pathetic announcement broadcast on the Moscow home service by the Ministry of Light Industry of the Russian republic in mid-October offered conservation-minded citizens two variants of plastic trees, one with shaggy "snow"covered branches and a new "fluffy", model, produced from granulated polythene by injection moulding. Both types had been awarded the state "quality mark", it was stressed.

How far the Soviet public has responded to this virtually unprecedented "commercial"' will be seen only on New Year's Eve. It is noteworthy, however, that so far no educationalist has thought fit to revise the song Russian children sing around the tree, "All in the woods was Yolka born, All in the woods she grew!"'

Vera Rich 